\title{
Erik Mueggler, The Age of Wild Ghosts. Memory, Violence, and Place in Southwest China
}

\section{Beatrice David}

\section{(2) OpenEdition}

12 Journals

Édition électronique

URL : http://journals.openedition.org/chinaperspectives/2403

DOI : 10.4000/chinaperspectives.2403

ISSN : 1996-4617

Éditeur

Centre d'étude français sur la Chine contemporaine

\section{Édition imprimée}

Date de publication : 15 septembre 2007

ISSN : 2070-3449

Référence électronique

Beatrice David, «Erik Mueggler, The Age of Wild Ghosts. Memory, Violence, and Place in Southwest China ", China Perspectives [En ligne], 2007/3 | 2007, mis en ligne le 09 avril 2008, consulté le 21

septembre 2020. URL : http://journals.openedition.org/chinaperspectives/2403 ; DOI : https://doi.org/ 10.4000/chinaperspectives.2403

Ce document a été généré automatiquement le 21 septembre 2020.

(C) All rights reserved 


\title{
Erik Mueggler, The Age of Wild Ghosts. Memory, Violence, and Place in Southwest China
}

\author{
Beatrice David
}

1 A revised edition of a doctoral thesis presented at the University of Michigan, The Age of Wild Ghosts is the result of over a year's field work carried out between the end of the 1980 s and the beginning of the 1990s in Zhizuo, a village in the autonomous Yi prefecture of Chuxiong, in the north of Yunnan in southwest China. The majority of the inhabitants of the village are officially part of the Yi minority nationality, which includes several groups who speak Tibeto- Birman dialects This official ethnic identity does not, however, replace for that of Lòlop'ò (in Chinese Luoluopo) which inscribes this group locally in the former territory made up of the twenty-odd hamlets of the village of Zhizuo before the beginning of the "Age of Wild Ghosts."

2 This metaphor, which provides the title of the book and of one of its chapters, designates the present time, which began with the famine provoked by the Great Leap Forward in 1958. The Age of Wild Ghosts was not yet over in the 1990s, when the anthropologist undertook his ethnographic journey through the real and symbolic places infused with the memory of the wounds and suffering inflicted during the two great tragedies of Maoism-the Great Leap Forward and the Cultural Revolution.

Among the vast production in the American field of the anthropology of contemporary China, Eric Mueggler's book stands out through the quality of its writing, which is in the best and noblest tradition of an anthropology not seeking to conceal, behind a screen of post-modern verbiage, the poverty of its ethnographic work or even the banality of its subject. This ethnography of an non- Han population in southwest China is in no way tributary to a culturalism fascinated by the otherness of its minority subject. While concentrating on the study of the cultural and social configurations particular to the Lòlop'ò, this religious anthropology, which goes to the heart of the political, seeks to understand how the inhabitants of these mountains in Yunnan faced the loss and pain produced by a predatory state, as well as their own responsibility 
during those violent events, which also involved the collusion of some who were close to them.

Opening with a funeral dirge, the exploration of this "geography of pain" first passes through the intimate places of dreams where affected individuals express their suffering, such as that which stems, in the case presented, from the violence exerted by the state on individuals during the recent campaigns to sterilise mothers over forty who had given birth to at least two children. The anxiety experienced through the loss of this reproductive capacity takes on its full dimension in light of the consequences attributed to an operation (the tying of the Fallopian tubes) which, by slowing the flow of sexual energy, distorts the woman's capacity for life and work. The power of the state over the intimacy of the family thus has implications which go far beyond the objective of birth control, since, through the body of the woman, it affects the capacity for work she represents in the family economy.

The therapy employed is ritual intervention, which calls on the services of a specialist entrusted with identifying the source of evil in the body of the suffering woman, and then eliminating it by exorcism. The study of this ritual pays particular attention to the poetic language used in the ritualised speech of the funeral laments and of the incantations of the exorcist, of which the author carefully reproduces a transcript in the original lolongo, the Lòlop'ò dialect. However, despite the creativity brought to the analysis by references to authors as inspired as Bachelard and Merleau-Ponty, despite the elegance of the writing, the anthropologist's interpretation, according to which the spirit emanating from a dead domestic animal held to be responsible for the mother's troubles is a metaphor for the state's official threat to attack her reproductive capacities, is not entirely convincing. Further examples would perhaps have helped to support this interpretation.

6 The home is another place where the state deeply affects domestic life, as is reflected in the changes made to traditional dwellings. In the study of the practices and representations of domestic space in chapter three, one is particularly struck by the pertinent analysis of the impact of the disappearance of the grain attic on the position of women in the family economy.

7 In the landscape of collective memory haunted by the losses of a deadly era, wanders the persistent shadow of a "body" left for dead during the last assaults of the Cultural Revolution in 1966, ready for reincarnation. This is the ts'ici, the institution particular to this region of northern Yunnan (huotou in Chinese) which administered a territory whose boundaries coincide with those of the present-day administrative village of Zhizuo. Chapters 4 and 5 offer a fascinating study of this system of territorial organisation in which the author concentrates on reconstructing the idealised image of a community imagined as a domestic group held together by the worship of a couple of common founding ancestors, as sketched out today by his favoured interlocutors. Be they former specialists in rituals carried out in the name of the community, or members of households which once held the honorific title of head of ts'ici (entrusted each year to a family able to meet the heavy expenses of this burden), all bear the wounds of its disappearance, the memory of the violent deaths associated with it, and the desire for the rebirth of a system which sketches the boundaries of the territory of Lòlop'ò identity.

8 The following three chapters show how the stories of the acts of vengeance committed by the wild ghosts are manipulated in order to divide responsibility for the wounds and 
losses inflicted during that era of violence, between the representatives of a state imagined as a spectral and predatory entity, based in a faraway political centre (Beijing), and its local agents, recruited among neighbours and family. All are possessed by the baleful stench of that era of violence.

9 Chapter 6 ("A Spectral State") recounts the gradual but irresistible destitution of the ts'ici system from the beginning of land reform. Held to be a "feudal superstition," the institution of the ts'ici was deprived of all economic and political authority. It survived in a deeply altered form at the beginning of the regime, through rituals and by preserving the fields which constituted the ancestral commonwealth of the ts'ici in Zhizuo. The last vestiges of this political-ritual system succombed to the violent assaults launched at the beginning of the Cultural Revolution.

10 Chapter 7 ("A geography of pain"), interrupts the story of the political events behind the violent deaths in the "age of wild ghosts" and continues the subtle description and analysis of the rituals of exorcism which began at the beginning of the book. Based on a rich ethnography, this essential classical study of the rituals and chants of exorcism carried out by Li Wenyi, a former specialist of ts'ici rituals, who was over eighty years old at the time of the author's study, is a remarkable demonstration of how the phenomena of possession, attributed to the wild ghosts of the victims of recent political violence, form part of a traumatic intrusion into present losses and past suffering. The author follows, step by step, the itinerary of Li Wenyi's exorcism chants, from the site of the affliction in Zhizuo to its final destination, the faraway capital, Beijing, the centre of a nation where the dignitaries of the spectral bureaucracy gather, at their head powerful spirits who died violent deaths themselves, such as Lin Biao (elevated by the exorcist to the rank of King of the Wild Ghosts) and Jiang Qing, Mao's wife. An extract of the chant runs like this: "Go toward Beijing where the King of the Wild Ghosts lives. Every day they have meetings there. Lin Biao died in a plane crash, Jiang Qing hanged herself. Go to the King of the Wild Ghosts, Lin Biao [...]" (p. 235). This is a remarkable example of the potential for innovation of the shamanic chant, which is always prepared to introduce elements of present political reality.

11 Chapter 8 ("The Age of Wild Ghosts") plunges back into the storm of political events during the Cultural Revolution. The profanation of the reliquary of the ancestors of the ts'ici during the Movement for Socialist Education against "superstitious sects" in 1965, transformed these figures of symbolic authority into wild ghosts, who were to pursue the local cadres and activists held responsible for the misfortunes which have overwhelmed the community since the famine of the Great Leap Forward. The scene which describes the sacrilege of the ancestors' reliquary, stained by the menstrual blood of a young activist from the region, is particularly striking. The young girl, suffering from dementia, was to commit suicide shortly afterwards and through her violent death, join the horde of Wild Ghosts (pp. 255-258). At the beginning of the 1970s, the Party Secretary felled the two trees which sheltered the spirit of the patron divinity of ts'ici in Zhizuo, and which until then had been spared. His accidental death in 1978 was, quite logically, attributed to the vengeance of this symbolic institution.

The implementation of economic reforms during this time did not mark the end of the torments inflicted by the Wild Ghosts of these unfortunate dead and the deified territorial powers, despite the proliferation of exorcisms at the time. Once again the plots of arable land of the former commonwealth of the ts'ici were at the heart of another series of tales and rumours of violent deaths and manifestations of possession, 
attributed to the Wild Ghosts. No family in the valley would run the risk of renting fields whose yield once went to paying for the rituals of the ts'ici, in order to avoid exposing themselves to the vengeance of the guardian spirit of those fields. At the beginning of the 1990s, the powerlessness of local cadres inspired a villager to say: "These good-for nothings and idiots will not be able to resolve the question of the renting of the fields belonging to the ancestral commonwealth until the Party authorises the restoration of the ts'ici" (p. 280).

13 The compulsory sterilisation campaigns in 1993 shattered this dream of a community becoming once again the master of its own destiny. The final chapter, entitled " $\mathrm{A}$ Broken Gourd," a reference to a fateful episode during a dance festival held some time after the sudden end of the sterilisation campaign, concludes this brilliant book with the moving image of a woman defying, with a wild dance, the authority of a state which has declared its mountain people to be obsolete.

14 Translated by Michael Black 